\title{
UK physiotherapy and haemophilia: A future strategy built on past success
}

Melanie Bladen, David Stephensen, Paul McLaughlin

From its humble beginnings in 1990, the UK's Haemophilia Chartered Physiotherapists Association (HCPA) has led the development of haemophilia physiotherapy in the UK and increasingly across Europe too. Over the past 10 years, the growth of the group has centred on an annual professional meeting that facilitated educational opportunities and professional networking, and has increasingly promoted research among members. The HCPA has now established a Clinical Studies Group, an open forum designed to identify and support research needs and to promote a collaborative approach to research that will answer some of the important questions that remain about haemophilia care.

Keywords: physiotherapy, HCPA, research

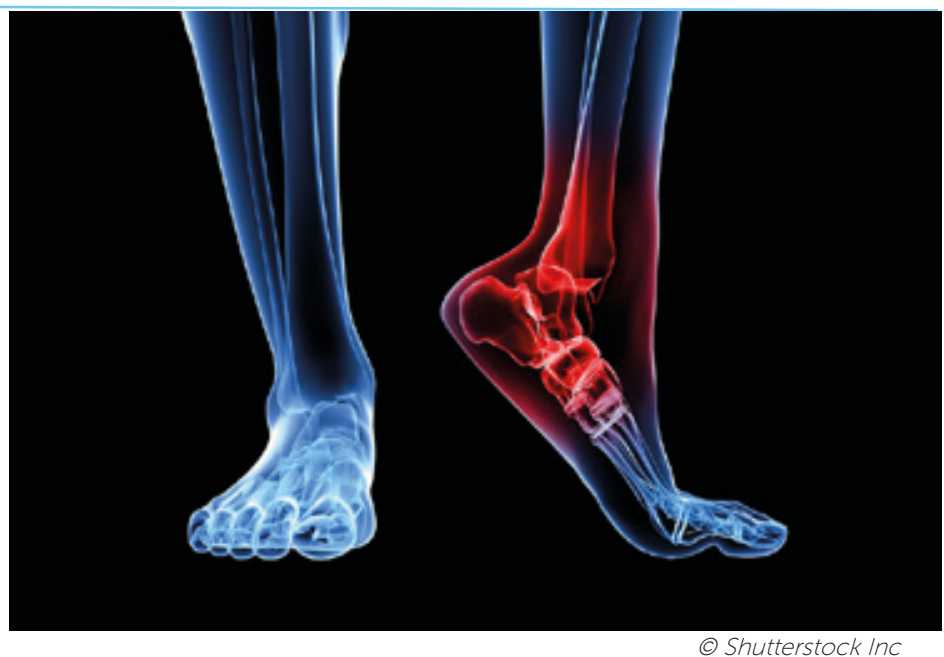

The Haemophilia Chartered Physiotherapists Association was formed in the UK in 1990. A notice was posted by Brenda Buzzard in the journal Physiotherapy announcing a recently formed group established "to promote the interchange of ideas about the management of patients with congenital bleeding disorders". She and four colleagues - Karen Beeton, Ruth Bolton, Fiona Hall and Fiona McChesney had already held one meeting, a few months earlier at the Royal Free Hospital, London, and they wished to develop a forum for communication via a newsletter and regional meetings. Indeed, a series of meetings were then organised at haemophilia centres around the UK, allowing participants to share experience of current practice and particularly to discuss complex clinical cases. This was in the difficult era of the medical management of patients infected with HIV and hepatitis $\mathrm{C}$; many were very sick and management of haemophilia often took a secondary place to those diseases. But over time, the HCPA began to flourish. Members became involved in the WFH musculoskeletal committee;

Melanie Bladen MSc

Physiotherapist, Great Ormond Street Hospital for Children NHS Foundation Trust, Great Ormond St, London WC1N 3JH, UK

Email: Melanie.Bladen@agosh.nhs.uk

David Stephensen PhD

Physiotherapist, Kent Haemophilia \& Thrombosis Centre, Canterbury, UK Email david.stephensenanhs.net

Paul McLaughlin MSc

Physiotherapist, Katharine Dormandy Haemophilia Centre and Thrombosis unit, Royal Free Hospital NHS Foundation Trust, Pond St, London, NW3 2QG, UK

Email: p.mclaughlinanhs.net

they networked with international colleagues; and they put together programmes for meetings that would develop clinical standards.

The impetus to take the group to the next level and to establish a national meeting of haemophilia physiotherapists came from the then Medical Director of Bayer, Professor lan Hann, formerly Professor of Paediatric Haematology and Oncology at Great Ormond Street Hospital. He identified the need to provide CPD and support for physiotherapists in haemophilia, similar to that which was available to the specialist nurses. He offered to sponsor a meeting, which would give an opportunity for physiotherapists to identify their own learning needs, allowing the invitation of external speakers and worldwide experts in the field. The offer was enthusiastically accepted by physiotherapists.

Those leading it's development (Melanie Bladen, David Stephenson and later Paul McLaughlin) identified a clear set of aims. At a time when very little current practice was evidence-based or research-orientated, and was instead largely based on individual case studies and "on-the-job" learning, the physiotherapists felt there was a clear need to establish a regular supported meeting that would seek to improve and ensure academic content. The meeting would also provide an excellent opportunity for peer-support and networking, so that physiotherapists who were working with complex clinical presentations could discuss management approaches with others. Finally, the meeting would also seek to promote research among physiotherapists.

The first meeting was held in Birmingham in 2007, the year in which it was prospectively demonstrated for the first time that prophylaxis with recombinant factor VIII can prevent joint damage and decrease the frequency of joint and other 
haemorrhages in young boys with severe haemophilia A [1]. On the basis of this publication, prophylaxis came to be accepted as the gold standard treatment for haemophilia.

Several eminent specialists were invited to speak at the inaugral meeting. They included Frank van Genderen, who had devised the Haemophilia Activities List (and later the PedHAL), Pam Hilliard, who had been instrumental in the development of the Haemophilia Joint Health Score, Bjorn Lundin who discussed MRI and joint pathology, and Natalie Jansen, who had worked with Goris Roosendaal and been involved in the studies that had provided evidence to support current advice on PRICE and non-weightbearing in the early days of haemophilic bleeding [2]. This meeting established a tradition that continued with subsequent meetings (Table 1 ), which have now covered a comprehensive range of clinically relevant topics, all of which have been based on the groups own identified learning needs as well as feedback received from meeting attendees. It is notable that in the early HCPA meetings, the lack of expertise in the UK meant there was a need to invite international speakers to speak at meetings. This is no longer the case. The expertise in physiotherapy globally is now well represented in the UK.

The 2007 meeting was attended by 20 physiotherapists; by 2016 there were 34 physiotherapists in regular attendance. As the number of physiotherapists employed (or with protected hours) within the UK's haemophilia centres has grown, so too has the level of professionalism of those in practice.
Key achievements in the last decade have included:

- An established annual national meeting

- Inclusion of a 'free paper' session at the annual meeting, allowing members of the HCPA to present ongoing research work, as well as provide a safe and supportive forum in which to develop the skills required to submit such work to international meetings. Meeting sponsorship has allowed for a CPD bursary to be allocated to the winning free paper at the meeting, and so those HCPA members who get the opportunity to go to the international meetings to learn and network are able to bring back new information to share with our colleagues

- Standardised HJHS teaching

- Development of Standard of Care documents for adult and paediatric physiotherapy services, based on the Chartered Society of Physiotherapy (CSP) professional standards framework.

- Increasing engagement in clinical research enhancing the knowledge base of the profession

- Collaboration between physiotherapists at different centres has grown as a result of the network forged by the HCPA, leading to a more cohesive professional group - An established web-based peer-support forum on Haemnet (www.haemnet.com) where members can meet and share problems and issues. It also has a platform within The Journal of Haemophilia Practice in which members can present cases

- Strengthening interdisciplinary relationships with the UK

Table 1: Topics addressed at HCPA meetings and invited speakers, 2007-2015

\begin{tabular}{|c|c|c|}
\hline Year & Topics & External Speakers \\
\hline 2007 & $\begin{array}{l}\text { Classifying sports by risk / HAL / Prophylaxis and joint outcomes / HJHS / } \\
\text { MRI and joint pathology / Pathogenesis of haemophilic athropathy }\end{array}$ & $\begin{array}{l}\text { Frank Genderen / Pam Hilliard / } \\
\text { Bjorn Lundin / Nathalie Jansen }\end{array}$ \\
\hline 2008 & $\begin{array}{l}\text { ICH in children / ICH in children with haemophilia / Ankle pathology / Up- } \\
\text { date on gait study / Podiatry / Physio service / Haemophilic pseudotumors } \\
\text { / Tissue healing times }\end{array}$ & $\begin{array}{l}\text { Elizabeth Chalmers / Nick God- } \\
\text { dard/ Piet de Kleijn / Lee Short/ } \\
\text { Suzanne Docherty }\end{array}$ \\
\hline 2009 & $\begin{array}{l}\text { Normal gait/ Adult gait and ankle gait parameters / 3D gait analysis / } \\
\text { Physical activity in boys with haemophilia/ Obesity / Activity participation / } \\
\text { Case studies / Future of physiotherapy }\end{array}$ & $\begin{array}{l}\text { Sebastian Lobet / Frank van } \\
\text { Genderen / Emma Sherlock / } \\
\text { Danielle Douma / Kathy Mulder }\end{array}$ \\
\hline 2010 & $\begin{array}{l}\text { Prophylaxis/ Synoviorthesis / Sex and the psoas / Pain management /case } \\
\text { studies }\end{array}$ & $\begin{array}{l}\text { Peter Collins / Nick Goddard/ } \\
\text { Greig Blamey }\end{array}$ \\
\hline 2011 & $\begin{array}{l}\text { Outcome measures (adult and child) / Obesity and nutrition /Obesity and } \\
\text { foot/ lower limb / Case studies }\end{array}$ & $\begin{array}{l}\text { Marjoleine Stafford / Stewart } \\
\text { Morrison }\end{array}$ \\
\hline 2012 & $\begin{array}{l}\text { Muscle haematomas and sports medicine / Haematomas and haemophilia } \\
\text { / Pseudotumors and imaging/ Rehabilitation / Debate on plyometrics and } \\
\text { electrotherapy }\end{array}$ & Zoe Hudson / Emma Sherlock \\
\hline 2013 & $\begin{array}{l}\text { NHS Clinical Reference Group for Haemophilia / Future of commissioning } \\
\text { / HJHS study day }\end{array}$ & $\begin{array}{l}\text { Gerry Dolan / Pam Hilliard / } \\
\text { Nichan Zourikan }\end{array}$ \\
\hline 2014 & $\begin{array}{l}\text { Joint scoring / Coagulation mechanisms / Lab investigations / Ultrasound } \\
\text { /abstracts }\end{array}$ & $\begin{array}{l}\text { Keith Gomez / Jane Needham / } \\
\text { Peter Collins }\end{array}$ \\
\hline 2015 & $\begin{array}{l}\text { Research / Inhibitors (medical and acquired) / management of children } \\
\text { and adults / abstracts / Foot and ankle problems }\end{array}$ & $\begin{array}{l}\text { Mike Makris / Mary Mathias / } \\
\text { Peter Briggs }\end{array}$ \\
\hline 2016 & Psychology 0-18 / 18+ / Case studies & $\begin{array}{l}\text { Zoe Berger / Lindsay Hughes/ } \\
\text { Nicola Dunne }\end{array}$ \\
\hline
\end{tabular}


Haemophilia Nurses Association, which in turn is helping to identify and develop better models of patient-centred care and research opportunities (such as the SO-FIT study [3])

- Greater national influence on care pathways and guidelines through HCPA representation on the NHS England Clinical Reference Group, being part of the development of the service specification for care in England, as well as UK Haemophilia Doctors Organisation (UKHCDO) Outcomes and Musculoskeletal working parties

- Membership of the UK Clinical Research Network Bleeding Disorders Clinical Studies Group.

- Closer collaboration and support through the above activities has resulted in a wider acceptance and appreciation of the role and status of the haemophilia physiotherapist in the UK, with a greater national voice and an increased presence within the international haemophilia community and global haemophilia meetings. It is acknowledged that there is always more work to do. There remains an ongoing need to establish standardised outcomes for the different age groups in haemophilia. This should be a cradle-to-grave approach, whereby for example, if a child has an ankle bleed there are set outcomes that will assess and monitor changes from a clinical and patient perspective. Likewise those clinical and patient identified problems in the elderly population can be systematically identified and monitored. The HCPA has identified outcomes, both as a measure of the disease process, and a measure of intervention success, as a key point for development in the coming years.

\section{The HCPA Clinical Studies Group}

One very tangible demonstration of the rise in professionalism of the UK's physiotherapists can be seen in Table 2 that lists the 32 papers published in the past 10 years that included UK haemophilia physiotherapists in their authorship. By contrast, from 1996 to 2005, there were just 15 papers published that included UK physiotherapists as authors. This rise in publications has been made possible as a direct result of regular meetings that have facilitated collaboration, sharing of ideas and peer support.

The 15 papers prior to 2006 primarily focussed on case

\section{Table 2: Publications involving HCPA members, 2006-15}

\section{Citation}

Bladen M, Main E, Khair K, Hubert N, Koutoumanou E, Liesner R. The incidence, risk and functional outcomes of intracranial haemorrhage in children with inherited bleeding disorders at one haemophilia centre. Haemophilia. Haemophilia. 2016 May 19. doi: 10.1111/hae.12938.

Nijdam A, Bladen M, Hubert N, Pettersson M, Bartels B, van der Net, J, Liesner R, Petrini P, Kurnik K, Fischer K. Using routine Haemophilia Joint Health Score for international comparisons of haemophilia outcome: standardization is needed. Haemophilia. 2015 Jul 14. doi: 0.1111/hae.12755. [Epub ahead of print]

Mann H, McLaughlin P. Musculoskeletal care in haemophilia: the importance of the joint team approach. J Haem Pract 2015; 2(2):17-19. doi: 10.17225/ jhp00054

McCarthy A, Moore A, Redhead L, McLaughlin P, Iorio A, Chowdary P. Development of haemophilic arthropathy of the ankle: results of a Delphi consensus survey on potential contributory factors. Haemophilia. 2015 Jan;21(1):116-23.

Wells AJ, McLaughlin P, Simmonds JV, Prouse PJ, Prelevic G, Gill S, Chowdary P. A case-control study assessing bone mineral density in severe haemophilia A in the UK. Haemophilia. 2015 Jan;21(1):109-15.

Hopper D. Successful use of Kinesio tape to treat an acute muscle haematoma. J Haem Pract 2014; 2(1):12-15. doi: 10.17225/jhp.00042

McLaughlin P, Bladen M, Holland M, Khair K. Joint assessment in haemophilia - current physiotherapist practice in the UK. J Haem Pract 2014; 1(3):

9-13. doi: 10.17225/jhp.00029

Stephensen D, Drechsler WI, Scott OM. Influence of ankle plantar flexor muscle architecture and strength on gait in boys with haemophilia in comparison to typically developing children. Haemophilia. 2014 May;20(3):413-20.

Stephensen D, Drechsler WI, Scott OM. Outcome measures monitoring physical function in children with haemophilia: a systematic review. Haemophilia. 2014 May;20(3):306-21.

Khair K, Bladen M, Holland M. Physical function and quality of life in adolescents with haemophilia (SO-FIT study). J Haem Pract 2014; 1(2): 11-14. doi: 10.17225/jhp.00018A

Bladen M, Main E, Hubert N, Koutoumanou E, Liesner R, Khair K. Factors affecting the Haemophilia Joint Health Score in children with severe haemophilia. Haemophilia. 2013 Jul;19(4):626-31.

McLaughlin P, Chowdary P, Woledge R, McCarthy A, Mayagoitia R. The effect of neutral-cushioned running shoes on the intra-articular force in the haemophilic ankle. Clin Biomech (Bristol, Avon). 2013 Jul;28(6):672-8.

Souza FM, McLaughlin P, Pereira RP, Minuque NP, Mello MH, Siqueira C, Villaça P, Tanaka C. The effects of repetitive haemarthrosis on postural balance in children with haemophilia. Haemophilia. 2013 Jul;19(4):e212-7.

Rangarajan S, Austin S, Goddard NJ, Négrier C, Rodriguez-Merchan EC, Stephensen D, Yee TT. Consensus recommendations for the use of FEIBA( $($ ) in haemophilia A patients with inhibitors undergoing elective orthopaedic and non-orthopaedic surgery. Haemophilia. 2013 Mar;19(2):294-303.

Stephensen D, Rodriguez-Merchan EC. Orthopaedic co-morbidities in the elderly haemophilia population: a review. Haemophilia. 2013 Mar;a19(2):166-73.

Stephensen D, Drechsler WI, Scott OM. Biomechanics of lower limb haemophilic arthropathy. Blood Rev. 2012 Sep;26(5):213-21.

Sørensen B, Benson GM, Bladen M, Classey S, Keeling DM, McLaughlin P, Yee TT, Makris M. Management of muscle haematomas in patients with severe haemophilia in an evidence-poor world. Haemophilia. 2012 Jul;18(4):598-606. 
Solimeno L, Luck J, Fondanesche C, McLaughlin P, Narayan P, Sabbour A, Sohail T, Pasta G. Knee arthropathy: when things go wrong. Haemophilia. 2012 Jul;18 Suppl 4:105-11.

Heim M, Beeton K, Blamey G, Goddard N. Management of the elbow joint. Haemophilia. 2012 Jul;18 Suppl 4:101-4.

Stephensen D, Drechsler W, Scott O. Comparison of muscle strength and in-vivo muscle morphology in young children with haemophilia and those of age-matched peers. Haemophilia. 2012 May;18(3):e302-10.

Blamey G, Forsyth A, Zourikian N, Short L, Jankovic N, De Kleijn P, Flannery T. Comprehensive elements of a physiotherapy exercise programme in haemophilia - a global perspective. Haemophilia. 2010 Jul;16 Suppl 5:136-45.

Sherlock E, O'Donnell JS, White B, Blake C. Physical activity levels and participation in sport in Irish people with haemophilia. Haemophilia. 2010 Jan;16(1):e202-9.

Stephensen D, Tait RC, Brodie N, Collins P, Cheal R, Keeling D, Melton K, Dolan G, Haye H, Hayman E, Winter M. Changing patterns of bleeding in patients with severe haemophilia A. Haemophilia. 2009 Nov;15(6):1210-4.

Stephensen D, Drechsler W, Winter M, Scott O. Comparison of biomechanical gait parameters of young children with haemophilia and those of agematched peers. Haemophilia. 2009 Mar;15(2):509-18.

Bladen M, Khair K, Liesner R, Main E. Long-term consequences of intracranial haemorrhage in children with haemophilia. Haemophilia. 2009 Jan;15(1):184-92.

d'Young Al. Conservative physiotherapeutic management of chronic haematomata and haemophilic pseudotumours: case study and comparison to historical management. Haemophilia. 2009 Jan;15(1):253-60.

d'Young Al. Domiciliary application of CryoCuff in severe haemophilia: qualitative questionnaire and clinical audit. Haemophilia. 2008 Jul;14(4):823-7.

Bladen M, Alderson L, Khair K, Liesner R, Green J, Main E. Can early subclinical gait changes in children with haemophilia be identified using the GAITRite walkway. Haemophilia. 2007 Sep;13(5):542-7.

Buzzard BM. Physiotherapy, rehabilitation and sports in countries with limited replacement coagulation factor supply. Haemophilia. 2007 Sep;13 Suppl 2:44-6

Beeton K, Neal D, Watson T, Lee CA. Parents of children with haemophilia--a transforming experience. Haemophilia. 2007 Sep;13(5):570-9.

Beeton K, De Kleijn P, Hilliard P, Funk S, Zourikian N, Bergstrom BM, Engelbert RH, Van Der Net JJ, Manco-Johnson MJ, Petrini P, Van den Berg M, Abad A, Feldman BM, Doria AS, Lundin B, Poonnoose PM, John JA, Kavitha ML, Padankatti SM, Devadarasini M, Pazani D, Srivastava A, Van Genderen FR, Vachalathiti R. Recent developments in clinimetric instruments. Haemophilia. 2006 Jul;12 Suppl 3:102-7.

Stephensen D. Rehabilitation of patients with haemophilia after orthopaedic surgery: a case study. Haemophilia. 2005 Nov;11 Suppl 1:26-9.

Heijnen L, Buzzard BB. The role of physical therapy and rehabilitation in the management of hemophilia in developing countries. Semin Thromb Hemost. 2005 Nov; 31(5):513-7.

Beeton K, Neal D, Lee C. An exploration of health-related quality of life in adults with haemophilia-a qualitative perspective. Haemophilia. 2005

Mar;11(2):123-32.

Collins PW, Bolton-Maggs P, Stephensen D, Jenkins B, Loran C, Winter M. Pilot study of an Internet-based electronic patient treatment record and communication system for haemophilia, Advoy.com. Haemophilia. 2003 May; 9(3):285-91.

Watson T. Current concepts in electrotherapy. Haemophilia. 2002 May;8(3):413-8.

Beeton K. Evaluation of outcome of care in patients with haemophilia. Haemophilia. 2002 May;8(3):428-34.

Yee TT, Beeton K, Griffioen A, Harrington C, Miners A, Lee CA, Brown SA. Experience of prophylaxis treatment in children with severe haemophilia. Haemophilia. 2002 Mar;8(2):76-82

Hicks JL, Ribbans WJ, Buzzard B, Kelley SS, Toft L, Torri G, Wiedel JD, York J. Infected joint replacements in HIV-positive patients with haemophilia. J Bone Joint Surg Br. 2001 Sep;83(7):1050-4.

Beeton K, Rodriguez-Merchan EC, Alltree J. Total joint arthroplasty in haemophilia. Haemophilia. 2000 Sep;6(5):474-81.

Buzzard BM. Physiotherapy for the prevention of articular contraction in haemophilia. Haemophilia. 1999 Mar;5 Suppl 1:10-5.

Buzzard BM. Proprioceptive training in haemophilia. Haemophilia. 1998 Jul;4(4):528-31.

Beeton K, Cornwell J, Alltree J. Muscle rehabilitation in haemophilia. Haemophilia. 1998 Jul;4(4):532-7.

Buzzard BM. Physiotherapy for prevention and treatment of chronic hemophilic synovitis. Clin Orthop Relat Res. 1997 Oct;(343):42-6

Ribbans WJ, Giangrande P, Beeton K. Conservative treatment of hemarthrosis for prevention of hemophilic synovitis. Clin Orthop Relat Res. 1997 Oct;(343):12-8.

Buzzard BM. Sports and hemophilia: antagonist or protagonist. Clin Orthop Relat Res. 1996 Jul;(328):25-30

studies and anecdotal evidence. There was a need for studies to utilise robust methodologies. The increased academic support and collaboration facilitated by the HCPA Annual Meeting, has led to an increase in research focussed work published by UK physiotherapists, with more than half of the 32 papers published in the past decade utilising diverse robust research methodologies.

The challenge now is to harness and to build on that dynamism for research in a collaborative manner in order to answer some of the important questions that remain about haemophilia care. For this reason the HCPA has established a Clinical Studies Group, an open forum designed to identify what needs to be done, and provide support and mentorship for those interested in research in their area of practice. Clinicians must be involved in research in order to provide the best practice to our patients. Research for 


\section{Haemophilia Group}

MADAM - The Haemophilia Chartered
Physiotherapists Association is a recently
formed group which has been established
to promote the interchange of ideas about
the management of patients with congenital
bleeding disorders. The group aims to
develop a forum for communication via a
newsletter and meetings, the first of which
was held in June this year at the Royal Free
Hospital, Hampstead.
Anyone who would like to be added to the
mailing list is invited to write to Brenda
Buzzard MCSP, Physiotherapy Department,
Royal Victoria Hospital, Newcastle.
KAREN BEETON MCSP
RUTH BOLTON MCSP
BRENDA BUZZARD MCSP
FIONA HALL MCSP
FIONA MCCHESNEY MCSP

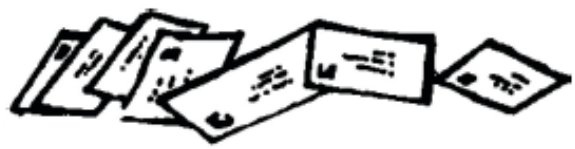

physiotherapists can take many forms, from individualinitiated research, systematically reviewing existing evidence to find the best approaches, to participating in research for others. The primary aim of the group is to support research and build capacity (Table 3). One way the group can support activity is to function as a forum to enable physiotherapists with an idea to bring it to the Clinical Studies Group, which would in turn help the physiotherapist develop that idea into a worthwhile research project. The group would also provide a support network for those already undertaking research to assist with recruitment to multi-centre research. By working within a group forum rather than in isolation, the hope is that physiotherapists can encourage each other to participate in each other's research. This should lead to robust clinically relevant studies of high quality and sufficient numbers.
Looking to the future

There is increasing support available for physiotherapists to attend international meetings, such as those of the international Musculoskeletal Congresses of the World Federation of Haemophilia. In addition, physiotherapists are increasingly represented on the organising committees for WFH meetings, as well as being invited speakers at both the WFH world congress and the MSK congresses. At the more local level, the needs of continual professional development (CPD) and education pose challenges for the HCPA, which must work to ensure its annual meeting contains a scientific element while also remaining relevant to practising clinicians whether they manage adults or children on a day-to-day level.

At a professional level, across the UK, haemophilia physiotherapists are gaining more hours and greater representation in haemophilia centres. They are increasingly recognised as key members of the haemophilia multidisciplinary team, and the best-placed profession to deal with the musculoskeletal issues that patients present with. As a group, HCPA needs to further promote itself, highlighting to stakeholders in haemophilia care what haemophilia physiotherapy can do and more clearly define the role. Clearly, active participation in research is a key element of this in what is a golden age for musculoskeletal research in haemophilia, both in adult and paediatric care. Physiotherapists should no longer simply support other people's research and publications by generating data but are in an ideal position to identify research priorities and questions and lead research programmes that are designed to really benefit patient care. This will be greatly facilitated by the work of the Clinical Studies Group and the collaborative principles upon which it is predicated.

At an international level, HCPA members are represented on the physiotherapy groups of both the European Association for Haemophilia and Allied Bleedings Disorders (EAHAD) and the WFH, and are collaborating with a worldwide expert team in developing and writing teaching packs for physiotherapists new to haemophilia care.

There is a case for redefining the role of the physiotherapist within the haemophilia multidisciplinary team, and extend the boundaries of that role. Indeed, boundaries are already being pushed with the use of point-of-care real-time ultrasound, performing steroid injections, independent

Table 3: Aims of the Clinical Studies Group

To develop a haemophilia physiotherapy research group

To identify research priorities and generate evidence on which care is based

To build research capacity within physiotherapy and increase research activity by physiotherapists in haemophilia

To develop a support network

Support a good research experience and recommending it to others

To identify and deliver research of the highest quality

Collaborate with colleagues, patients and other clinicians

Include them in the way research is prioritised, designed and delivered 
prescribing rights and the use of diagnostic radiology in clinics. The very specific musculoskeletal components of haemophilia make this a logical development for physiotherapists. The aspiration should be to see the development of a consultant physiotherapist in haemophilia. Such a role should allow the profession to take the lead in developing pathways and care protocols, and driving research.

It is conceivable that in the future physiotherapists and nurses could facilitate patient review clinics, with medical colleagues being involved only when there is a medical emergency. For patients who report to be generally well and are well-treated in regards to prophylaxis, this is certainly a model that is likely to develop within the next few years, as the main issues being identified are MSK-related and/ or treatment-related. It is likely that the UK could drive forward this model, due to the quality of both nursing and physiotherapy practice in haemophilia care.

Haemophilia physiotherapy care together with the work of the HCPA in the UK has continued to develop since the HCPA was established in the early 1990s. There have been clear benefits of establishing a close working, collaborative group focussed on research and evidence-based practice. It is important that this work continues to enhance the musculoskeletal health of people with haemophilia and ensures that those with the condition receive the best and most appropriate care now and in the future.

\section{Disclosures}

The authors have advised no interests that might be perceived as posing a conflict or bias.

This is an Open Access article distributed under the terms of the Creative Commons Attribution License (http:// creativecommons.org/licenses/by/2.0), which permits unrestricted use, distribution, and reproduction in any medium, provided the original work is properly cited.

\section{Acknowledgements}

The HCPA would like to thank Bayer Healthcare for its ongoing commitment to the annual HCPA educational meeting

\section{References}

1. Manco-Johnson MJ, Abshire TC, Shapiro AD, Riske B, Hacker MR, Kilcoyne R, Ingram JD, Manco-Johnson ML, Funk S, Jacobson L, Valentino LA, Hoots WK, Buchanan GR, DiMichele D, Recht M, Brown D, Leissinger C, Bleak S, Cohen A, Mathew P, Matsunaga A, Medeiros D, Nugent D, Thomas GA, Thompson AA, McRedmond K, Soucie JM, Austin H, Evatt BL. Prophylaxis versus episodic treatment to prevent joint disease in boys with severe hemophilia. N Engl J Med. 2007 Aug 9;357(6):535-44.

2. Jansen NW, Roosendaal G, Lafeber FP. Understanding haemophilic arthropathy: an exploration of current open issues. Br J Haematol. 2008 Dec;143(5):632-40. doi: 10.1111/j.1365-2141.2008.07386.x.

3. Khair K, Bladen M, Holland M. Physical function and quality of life in adolescents with haemophilia (SO-FIT study). J Haem Pract 2014; 1(2): 1114. doi: $10.17225 /$ jhp. 00018

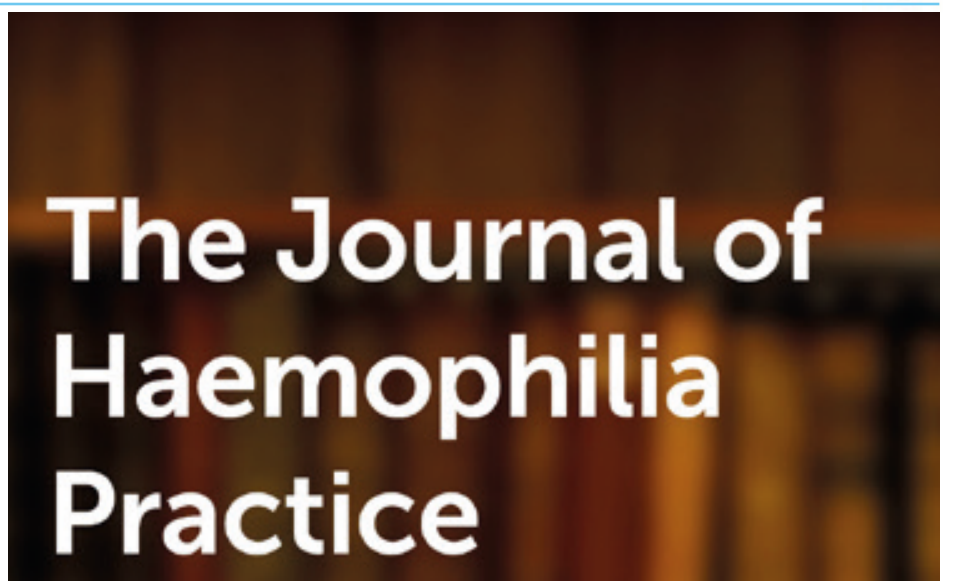

An open-access journal for sharing experience in the care of people with bleeding disorders

\section{www.haemjournal.com}

